\title{
A SÚPLICA DO AEDO FÊMIO PARA NÃO SER DEGOLADO (ODISSEIA 22, 342-53) ${ }^{1}$
}

\author{
Teodoro Rennó Assunção* \\ Recebido em: 15/11/2019 \\ Aprovado em: 20/12/2019
}

\begin{abstract}
RESUMO: Este artigo é uma tentativa ou ensaio de uma interpretação mais detida e precisa, por meio da tradução e principalmente do comentário detalhado, do texto grego da súplica do aedo Fêmio para não ser degolado por Odisseu na Odisseia (22, 342-53), levando em conta não apenas um entendimento vocabular e sintático adequado do texto desta súplica em sua básica função discursiva ou retórica, mas também a sua interpretação "literária", social e religiosa no contexto da Odisseia (mais especificamente) e da Ilíada, com uma atenção particular à palavra autodídaktos ("autodidata" ou "espontâneo"), cuja ocorrência aqui é a única (um hápax) em Homero.
\end{abstract}

PALAVRAS-CHAVE: Súplica; aedo Fêmio; "para não ser degolado"; Odisseia; autodidaktos.

THE SINGER PHEMIUS' SUPPLICATION NOT TO HAVE HIS THROAT CUT DOWN (ODYSSEY 22, 342-53)

\begin{abstract}
This article is an attempt or essay of a more detailed and accurate interpretation, through the translation and mainly the detailed commentary, of the Greek text of the singer Phemius' supplication not to have his throat cut down by Odysseus in the Odyssey (22, 342-53), taking into account not only an adequate lexical and syntactical understanding

\footnotetext{
${ }^{1} \mathrm{Um}$ primeiro esboço reduzido deste artigo foi apresentado como comunicação numa mesa-redonda no evento comum "V Congresso Brasileiro de Retórica e IV Jornadas da Associação Latino-Americana de Retórica”, que aconteceu de 20 a 24 de agosto de 2018 na Faculdade de Filosofia e Ciências Humanas e na Faculdade de Letras da Universidade Federal de Minas Gerais em Belo Horizonte. Agradeço vivamente as correções e sugestões das revisões cuidadosas de Antonio Orlando Dourado-Lopes e de Tatiana Ribeiro, que tornaram este texto mais limpo e mais claro.
}

Professor

Associado de língua e literatura grega, Faculdade de Letras, Universidade Federal de Minas Gerais. teorenno@gmail.com

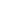


of the text of this supplication in its basic discursive or rhetorical function, but also its "literary", social and religious interpretation in the context of the Odyssey (more specifically) and of the Iliad, with a careful attention to the word autodidaktos ("self-taught" or "spontaneous"), whose occurrence here is the only one (a hapax) in Homer.

KEYWORDS: Supplication; singer Phemius; "not to have his throat cut down”; Odyssey; autodidaktos.

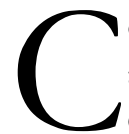

omo primeiro exercício de interpretação do conhecido discurso de súplica de Fêmio a Odisseu no canto 22 da Odisseia (incluindo os dois versos que o antecedem e definem a postura do aedo e o seu endereçamento), proponho aqui uma tradução provisória, sem nenhuma preocupação de estabelecer em português um padrão métrico correspondente ao do hexâmetro dactílico (ainda que tentando manter a unidade mínima de cada verso, para facilitar o cotejo) e atenta apenas a uma possível precisão semântica, tanto vocabular quanto sintática, na transposição aproximativa do que está dizendo o texto grego homérico: ${ }^{2}$

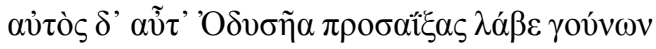

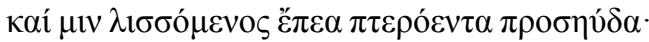

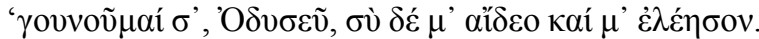

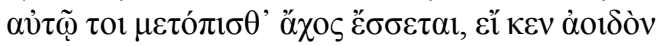

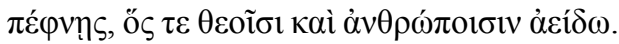

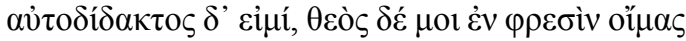

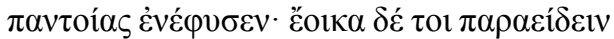

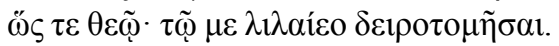

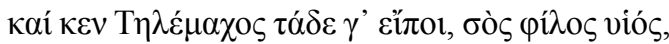

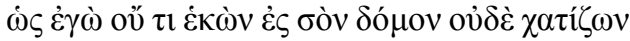

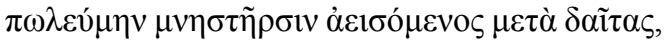

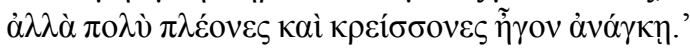

Ele mesmo, então, lançando-se pra Odisseu, pegou seus joelhos, e a ele, suplicando, dirigiu (enunciando-as) palavras aladas:

"Toco teus joelhos, Odisseu, e tu me respeita e tem compaixão.

Pra ti mesmo depois haverá sofrimento, se a um cantor matares, eu que canto tanto pra deuses quanto pra homens.

Sou autodidata, pois um deus no meu senso enredos variados faz brotar; e estou apto a cantar junto de ti como pra um deus; por isso não queiras me degolar.

\footnotetext{
${ }^{2}$ O texto grego da Odisseia usado é o da edição de Helmut van Thiel (Van Thiel, 1991), tendo sido cotejado com o da edição de Thomas W. Allen (Allen, 1919) e com o da de Peter von der Mühll (Von der Mühll, 1962). As traduções da Odisseia para o português, usadas para cotejo, são a de Christian Werner (Werner, 2014), e a de Frederico Lourenço (Lourenço, 2003). E as traduções para o português das passagens da Odisseia citadas em todo este artigo são todas de minha autoria, seguindo os mesmos critérios enunciados logo acima no primeiro parágrafo do texto principal.
} 
E Telêmaco, teu caro filho, poderia te dizer essas coisas: que eu, não de bom grado nem buscando algo, tua casa frequentava pra cantar após os banquetes pros pretendentes, mas (eles), bem mais numerosos e mais fortes, me conduziam, forçado."

(Odisseia 22, 342-53)

Um primeiro comentário sobre os dois versos que introduzem este discurso (definindo-o, pelo gesto ritual e o modo de enunciação, como uma suplicação), assim como seu primeiro verso, permitiria também situá-lo, como a segunda, no conjunto de três suplicações para Odisseu (ou Telêmaco): a de Leodes, a de Fêmio e a de Médon (todos três, "profissionais" da palavra), que sucedem a matança de todos os pretendentes (a única exceção, deixada para o final, sendo a morte ultraviolenta de Melântio, cf. $O d$. 22, 474-7). O índice formal mais evidente desta conexão (sobretudo com a primeira súplica) é a exata repetição do segundo verso da introdução e do primeiro da súplica que introduzem também a súplica do arúspice Leodes, ${ }^{3}$ que, no entanto (e diferentemente de Fêmio e do arauto Médon), não é poupado, dando assim à súplica de Fêmio um destaque contrastivo, por ser ela a que também torna possível que Médon seja poupado (algo que jamais ocorre na Ilíada com nenhum suplicante). ${ }^{4}$

Mas a súplica de Fêmio se distingue também das outras duas por conter toda uma larga cena introdutória pelo narrador (cf. Od. 22, 330-41), em que o cantor é apresentado como "filho de Térpio (Doador-de-prazer)", "que cantava aos pretendentes, forçado" (Od. 22, 330-1), como se justificando antecipadamente o argumento final de Fêmio; ${ }^{6}$ sendo em

\footnotetext{
3 “The text has Phemius repeat the same gestures already performed by Leodes. The lines are repeated verbatim: Od. 22.342-44 = Od. 22.310-12.” (Pucci, 1987, p. 228, n. 2). O verso 310, no entanto, não é repetido verbatim pelo verso 342, e apenas o segundo hemistíquio é o mesmo do verso 365 (descrevendo Médon em relação a Telêmaco), como foi bem notado por Ameis-Hentze: "342. Erstes Hem. $=u$ 165, zweites $=365 .-343.344=311$ f., w. s.” (Ameis-Henze, 1911, p. 121).

4 "The last phase of the battle consists of a series of three supplications: Leodes (310-29), Phemius (330-60 + 378-80), and Medon (361-80); an instance of a triadic structure. 'Supplication' scenes are regularly found in the context of a battle (cf., e.g., Il. 11.122-47; 20.463-72; or 21.64-119), but never in a row, as here. The effect of the juxtaposition is to put into relief the sparing of the life of the singer Phemius, following as it does upon the non-sparing of the seer Leodes." (De Jong, 2001, p. 537).

5 "It is at this momentous point that the text, for the only time, calls him Terpiades [...], as if to evoke, at the moment of his threatened death, the pleasure he created and for which he pays so dearly." (Pucci, op. cit., p. 228). "330-2. Terpiádēs ... Phếmios: 'Fame-giver' [...] or 'Laysman [...], son of Delight' (térpō), a Significant Name for a Bard.” (Stanford, 1958, p. 385). “330. Phemius [...] has another of the Odyssey's significant names, 'Fame-giver' or 'Rich in lays' [...]; here reinforced for the first time by the significant patronymic name 'son of Terpis or Terpius, Giver of delight [...]." (Fernández-Galiano, 1992, p. 278).

6 'The information that Phemius sang for the Suitors 'by compulsion' is a strategically placed internal repeating analepsis (cf. 1.154): soon the singer will stress this fact when begging Odysseus for his life." (De Jong, 2001, p. 539).
} 
seguida descrito, "sustendo nas mãos a lira aguda" $(\mathrm{Od} .22,332),{ }^{7}$ numa deliberação típica entre duas alternativas (mermèrízen): ${ }^{8}$ aqui entre refugiar-se no altar de Zeus (o que anuncia o seu destino final, nesta cena triádica, juntamente com Médon) ${ }^{9}$ ou agarrar os joelhos de Odisseu para suplicar-lhe, decidindo-se pela última (cf. Od. 22, 332-9); e, enfim, depondo a lira no chão "entre a ânfora e a poltrona cravejada-de-prata" (cf. Od. 22, 340), como se a situar bem o espaço e a ocasião do banquete em que ele exercia seu ofício.

Enfim, esta cena de súplica de Fêmio guarda ainda com a anterior de Leodes (além da estrita semelhança da introdução e do primeiro verso de ambas) uma conexão por ser na anterior que Odisseu se apropria da espada de Agelau morto (cf. Od. 22, 326-8), com a qual primeiramente irá impiedosamente decepar a cabeça de Leodes (que ainda balbucia algo, antes de se misturar à poeira, cf. Od. 22, 328-9), para depois ameaçar fisicamente Fêmio, que durante o seu discurso de súplica esclarece suficientemente ("por isso não queiras me degolar", $O d .22,349$ ) estar com uma espada possivelmente sobre sua nuca (estando ele ajoelhado aos pés de Odisseu), o que é confirmado também pelo pedido de Telêmaco para que Odisseu o poupe ("Contém-te, e não firas esse inocente com o bronze.", $O d .22,356$ ).

Mas a cena da suplicação de Fêmio contém (dentre as três) não apenas a maior introdução, mas também o maior discurso de súplica (dez versos, contra oito do de Leodes e apenas quatro do de Médon). E (mais importante) se atentamos para o conteúdo destes versos, constatamos que enquanto os discursos de Leodes e de Médon tentam justificar a súplica pela própria vida voltando-se para o reconhecimento dos crimes dos pretendentes e o seu respectivo não envolvimento com eles, o discurso de Fêmio apresenta não só este tipo de justificativa num segundo momento, mas também, num primeiro momento, uma justificativa que se volta para o possível grande ganho futuro que terá Odisseu, caso o poupe (ou seja: algo único entre os três, criando uma básica estrutura diádica, que também é única entre os três). ${ }^{10}$

\footnotetext{
7 “340-1. By giving two lines to the setting down of the Bard's lyre H. implies the care a musician always shows for his instrument [...]; but it should be remembered that the Homeric bard, as his name implies (aoidós, aeídein), was essentially a singer, not an instrumentalist like the later phormiktếs or kitharistếs." (Stanford, 1958, p. 385).

${ }^{8}$ Esclareço aqui que, com exceção das passagens maiores citadas dos textos gregos da Odisseia e do Agamêmnon de Ésquilo, optei sempre, por comodidade (e facilidade de leitura para os não familiarizados com o alfabeto grego), por transliterar em caracteres latinos as palavras, expressões ou frases em grego antigo, mesmo quando ocorriam não transliteradas nos textos, léxicos ou comentadores.

9 "The last two supplications are - uniquely - combined, and the connection between the two underlined by the reference to the altar of Zeus at the beginning and end (334-5 and 379) and the significant use of the dual to refer to Phemius and Medon in 378-80.” (De Jong, 2001, p. 538).

${ }^{10}$ Esta estrutura diádica, a partir de uma relação básica com o futuro e o passado, não foi reconhecida por Irene de Jong em sua descrição da estrutura deste discurso: “334-53 The structure of Phemius' 'supplication' speech is as follows: '(reference to speech-act of supplicating) I supplicate you: (request) have mercy on me. (reasons why supplicandus shoud accept the request) You will later regret having killed a singer, who sings for gods and mortals alike. I am self-taught and taught by a god. Singing for you, I seem
} 
Invertendo, no entanto, a cronologia interna deste discurso, irei começar pela segunda ou última parte, por ser ela a que, de algum modo, é comum aos outros dois discursos de súplica (o de Leodes e o de Médon), nesta grande cena triádica de suplicação pela vida (de três "profissionais" da palavra), após a matança dos pretendentes.

Esta segunda parte do discurso de súplica começa com um verso (o 350: "E Telêmaco, teu caro filho, poderia te dizer essas coisas") que é uma convocação do testemunho de Telêmaco (como se lembrando do discurso de defesa de Fêmio por ele no canto 1, 346-59), para dar maior objetividade (ou teor de verdade) à sua justificativa, mas também deste modo prefigurando a intervenção decisiva de Telêmaco em seu favor, junto a e em vez de Odisseu ("Contém-te, e não firas esse inocente com o bronze", 22, 356), ${ }^{11}$ que só se manifestará positivamente (cf. Od. 22, 372-7) após o discurso de súplica de Médon (curiosamente, por sua vez, endereçado a Telêmaco). ${ }^{12}$

O conteúdo desta justificativa, que apresenta a atividade do cantor (aeisómenos) na sua ocasião preferencial (metà daîtas, "após os banquetes”) ${ }^{13}$ e para o seu público majoritário (mnèstêrsin, "pros pretendentes"), como se insinuando a possível e interessada conformação do conteúdo do seu canto à necessidade de agradar a esta audiência majoritária (mesmo se precisasse mentir sobre o retorno de Odisseu, ao dizê-lo já morto, como sugere a defesa de Fêmio por Telêmaco no canto 1, cf. 354-5), se apoia basicamente na reivindicação desresponsabilizante de que esta atividade não foi praticada voluntariamente (oú ti hekốn, "não de bom grado"), nem visando a um ganho material (oudè khatízōn, "nem buscando algo"), ${ }^{14}$ mas "por constrição" ou "forçado" (anánkeè), termo que é utilizado antecipadamente pelo narrador para descrever seu modo de cantar não só no canto 22, mas também no canto I, no que poderia ser definido como uma dupla analepse (cf. Od. 22, 331 e Od. 1, 154), ${ }^{15}$ mas que, no fim deste discurso de Fêmio, é potenciado pelo verbo êgon ("conduziam”), indicando

to be singing for a god. Telemachus can testify that I only sang for the Suitors by compulsion (cf. 330-1n.), because I could not oppose them, who are more and stronger.” (De Jong, 2001, p. 539).

11 "Telemachus [...] intervenes immediately in defense of Phemius and tells Odysseus that the poet is anaitios, 'innocent' ( $O d$. 22.356), and Odysseus without a word - a rare reaction in epic and for him in particular to desist from a gesture without a comment - spares Phemius." (Pucci, 1987, p. 234).

${ }^{12}$ Estas inversões foram bem percebidas por Irene de Jong: "354-60 Instead of a reaction of the supplicandus Odysseus, we find an intervention by Telemachus (triggered by Phemius' own words: 350 ) [... 371 (iv) instead of a reaction from the supplicandus Telemachus, we have Odysseus' acceptance of Medon's and Phemius' supplications.” (De Jong, 2001, p. 539).

13 "Monro takes this as 'among their feasts' [...], explaining the accusative with metà in this sense as being due to the verb of motion, pōleúmēn [...]. But we learn from 1, $150 \mathrm{ff}$. and 8, 72-3 that it was the custom for the bard to sing after the feasting proper was over and Pindar apparently applies metadórpios to song in the sense of after supper. So it seems best to take the phrase closely with aeisómenos here and translate 'to sing for the Suitors after their banquets' [...]." (Stanford, 1958, p. 386). "metà daîtas nach den Mahlzeiten (vgl. metadórpios d 194) wenn die Männer noch beim Becher sitzen; s. th 73, a 152." (Ameis-Henze, 1911, p. 121).

14 “oudè khatízōn: 'nor much less in hopes (of any gain)'; [...].” (Fernández-Galiano, 1992, p. 281).

${ }^{15}$ Ver o comentário já citado de Irene de Jong na nota 6 . 
uma discreta violência, assim como pelo aposto do sujeito (expresso apenas na desinência número-pessoal do verbo finito na terceira pessoa do plural), "bem mais numerosos e mais fortes", que esclarece de onde vem o poder físico que garante o uso desta violência.

Caberia, enfim, retomar aqui, antes de comentarmos a primeira parte desta súplica de Fêmio, a associação que faz Pietro Pucci entre a qualificação dos pretendentes como "bem mais numerosos e mais fortes" e a fábula (ou aînos) do falcão e do rouxinol em Trabalhos e dias de Hesíodo (203-9) com sua justificação brutal do poder, ${ }^{16}$ assim como a suspeita, prenhe de um agudo sentido, de que esta retratação de Fêmio também se daria sob a ameaça de violência de seu novo senhor: Odisseu, que tem precisamente uma espada na mão (e possivelmente sobre sua nuca) e poderia degolá-lo a seu bel prazer. ${ }^{17}$

Voltemo-nos, então, para concluir (sem muita pressa) este comentário, para a primeira parte deste discurso de Fêmio (Od. 22, 344-9). Poderíamos, para começar, observar que ela é, de algum modo, enquadrada por um primeiro verso (o 344) terminando com uma "ordem" dupla mais genérica (ou seja: dois imperativos aoristos), justificada por sua posição vulnerável de suplicante: "tu me respeita e tem compaixão", e por um último verso (o 349) com uma "ordem" mais precisa (ou seja: um imperativo aoristo com um infinitivo), justificada por seu argumento quanto ao possível ganho futuro de Odisseu: "por isso não queiras me degolar", que constitui o núcleo do seu pedido para que sua vida seja poupada.

Notemos que optei aqui por uma tradução mais literal do infinitivo aoristo deirotomêsai ("degolar"), literalmente "cortar o pescoço", e que um escoliasta da Odisseia propõe equivaler a laimotomêsai ("cortar a garganta"), ${ }^{18}$ sentido um pouco mais preciso do que o de "decapitar" e que, como sugere P. Pucci (que o traduz por "to cut my throat", "cortar minha garganta"), poderia certamente guardar aqui alguma conotação sacrificial, mesmo que a vítima seja humana, ${ }^{19}$ e a despeito do fato de que na Ilíada este verbo é usado algumas vezes com o sentido genérico de "matar". ${ }^{20}$

\footnotetext{
${ }^{16}$ Ver Pucci, 1987, p. 233-4.

17 "It is claimed here that Phemius could not resist the pressure of the suitors and sang for them, as we know well [...]. Since Phemius recants under the same menace that induced him to sing for the suitors, we do not know whether he is now singing just what his heart and, or the Muse, or the pleasure of listeners wants him to sing - in a word, whether he complies again with necessity." (Pucci, 1987, p. 234-5).

18 “349. deirotomêsai] laimotomêsai. Q.” (Dindorf, 1855, p. 713).

19 "Probably the Odyssey has this text [i.e. the Lycaon episode (21.89) in the Iliad] in mind since, with the exception of 21.555, all the other uses of the verb [i.e. deirotoméo] refer to the killing of victims. Lycaon sees himself as a sacrificial victim, as does Phemius here." (Pucci, 1987, p. 229, n. 7).

20 " $[\ldots]$ it is not certain that deirotoméo and its compound in apo-always imply beheading; it does so in $O d$. xi 35 , of sheep, and $I l$. xxi 55, of dogs, and even in $I l$ xviii 336, and xxiii 22, of human victims, but $I l$ xxi 555 is less clear-cut, and in $I$. xxi 89 Lycaon fears that, with him dead, Achilles will have 'cut the throats', deirotoméseis, of both himself and his brother, though we know that he had killed Polydorus by a spear-thrust to the belly.” (Fernández-Galiano, 1992, p. 277).
} 
Passemos, então, à primeira proposição da justificativa para as “ordens" ou, melhor, "pedidos prementes" de Fêmio para não ser morto (que enquadram esta primeira metade da súplica): "Pra ti mesmo depois haverá sofrimento, se a um cantor/ matares, eu que canto tanto pra deuses quanto pra homens." (Od. 22, 345-6).

A primeira oração ("Pra ti mesmo depois haverá sofrimento"), uma apódose antecipada, é sabidamente ${ }^{21}$ a mesma utilizada por Odisseu, em sua fala para Aquiles no canto 9 da Ilíada (verso 249), quando descreve o provável sentimento futuro de Aquiles (traduzido às vezes mais especificamente por "remorso"), caso não renuncie em tempo à sua cólera e impeça a investida troiana (liderada por um furioso Heitor) e uma derrota desastrosa dos Aqueus, com a queima das naus (cf. Ilíada 9, 234-43). Será que Fêmio (ou, mais precisamente, "Homero" através dele) acenaria sutilmente aqui para a memória iliádica de Odisseu, colocando-o agora na posição de um "Aquiles" odisseico sem bom senso (já que quer exterminar todos que tenham tido uma relação qualquer com os pretendentes) e que em breve se arrependerá do que fez, como ocorre com o Aquiles iliádico após a morte de Pátroclo? ${ }^{22}$ Ou seria esta repetição de uma oração uma mera coincidência devido à construção formular dos versos homéricos (a partir de um grande estoque comum de fórmulas)?

A segunda oração ("se a um cantor/ matares, eu que canto tanto pra deuses quanto pra homens"), uma prótase posposta, joga etimologicamente com a definição da função social de Fêmio (aoidón, "cantor" ou "aedo") a partir de sua atividade designada pelo verbo "cantar" na primeira pessoa do singular (aeído, "canto"), valorizando-a pela definição abarcante e potenciada dos seus destinatários (theoîsin, "deuses", anthrốpoisin, "homens" ou "humanos"), se não diretamente, no caso dos deuses (que em Ítaca não participam dos banquetes, como outrora na Feácia, segundo Alcínoo, cf. Od. 7, 201-3), ao menos indiretamente como aqueles em honra dos quais uma parte ao menos das canções é cantada, no ambiente preferencial do banquete, que o mais das vezes é pós-sacrificial. ${ }^{23}$ Ainda que não seja propriamente definido aqui o repertório do canto de Fêmio, mas apenas os seus destinatários, a menção destes dois estatutos ou modos básicos de existência (com exclusão dos animais): um, em princípio, superior, "deuses", e outro, em princípio, inferior, "homens", permitirá na imediata sequência duas conjunções laudatórias (e retoricamente eficazes) destas duas esferas em princípio (ou aparentemente) bem distintas.

Comecemos pela segunda conjunção que, no conjunto, apesar de se prestar ao menos a duas interpretações diversas, suscitou muito menos polêmica interpretativa do que

21 "345 = I 249 - wird es leid sein.” (Ameis- Henze, 1911, p. 121). “345. [...] the same line-opening at Il. ix 249, where Odysseus prophesies similar remorse in Achilles' case if he does not yield." (Fernández-Galiano, op. cit., p. 279). Ver também Pietro Pucci na nota abaixo.

22 "In Il. 9.249 Odysseus uses the same expression when, speaking to Achilles, he tries to assuage his wrath and resentment. Phemius, and Homer on his behalf, is devilishly accurate in his choice of quotations, for indeed Achilles eventually did pay bitterly for not having subdued his wrath in time." (Pucci, 1987, p. 229, n. 3).

23 “346. theoîsin zu Ehren der Götter, bei Festen und Opfermahlzeiten; anthrốpoisin den Menschen zur Freude." (Ameis-Henze, 1911, p. 121). 
a primeira: "e estou apto a cantar junto de ti/ como pra um deus" (Od. 22, 348-9). Estas duas interpretações diversas partem de duas leituras diversas do verbo éoika (um perfeito, com sentido de presente, na primeira pessoa do singular, que é uma "ocorrência única" ou um bápax homérico), ${ }^{24}$ como bem percebido há muito tempo por David Monro (retomado tanto por Stanford quanto por Pucci): ou "convenho pra", "estou pronto pra", "estou apto a" - no caso, "cantar junto de ti/ como pra um deus" - que é o sentido preferido por Monro, Stanford e Pucci ${ }^{25}$ e também por mim, hipótese que pareceria paradoxalmente acentuar mais o valor de Fêmio do que o de Odisseu; ${ }^{26}$ ou "pareço", no sentido de "me sinto" - também aqui "cantar junto de ti/ como pra um deus" - sentido mais improvável, mas que caberia melhor para uma intenção laudatória de glorificar Odisseu.

De qualquer modo, ainda que a ênfase possa variar um pouco entre Fêmio como cantor e Odisseu como destinatário privilegiado do canto, Fêmio, por um lado, é situado cantando "junto de" (pará) Odisseu, numa posição de honra junto a seu senhor ${ }^{27}$ e Odisseu, por outro, o enfim reassumido "rei" (basileús) de Ítaca, continua a ser laudatoriamente comparado com um deus (theós). Assim, como W. Stanford bem observou quanto às duas diversas ênfases, "em ambos os casos hós te theôi ['como para um deus'] parece ser uma

24 "This personal construction with éoika is also [i.e. as paraeidein with dat. of person governed by the prefix, and implying the idea of having the seat of honor next to a superior] unique in Homer, though we have a parallel in Il. vii 193 dokéé nikeesémen Héctora 'it seems that I shall defeat Hector'. [...] éoike 'be fitting' is very common [...]; but I can find no parallel for the construction used personally in Homer (the use of the part. eoikốs 'fitting' at i 46, iii 12405, iv 239 is not strict parallel) [...]" (Fernández-Galiano, 1992, p. 281, sublinhados meus).

25 “348-9. éoika $k$. t. 1.: Monro renders 'I am fit to sing before you ...' i.e. 'I am the right person to be your poet', observing, 'it is not the glory of Ulysses, but the special worthiness of Phemius, that is insisted on'. Others, less convincingly, take it as 'I feel when singing before you as if I were singing in the presence of a god'." (Stanford, 1958, p. 385). P. Pucci, que traduz éoika por "I am fit to", diz na nota correspondente: "I translate this line in accordance with David B. Monro, Homer's Odyssey (Oxford: Clarendon Press, 1901), who discusses the other possible interpretation: 'I seem in singing to you, to be singing to a god.' The question, of course, is whether we should emphasize the worthiness of Phemius or the godlike portrait of Odysseus. To me it seems impossible to decide." (Pucci, 1987, p. 229, n. 6).

${ }^{26}$ Apesar de não estar falando da solução escolhida por Monro, esta proposição de M. FernándezGaliano se aplicaria também a ela: “[...] the gravest objection is that, phrased like this, Phemius' rather blatant piece of flattery [...] cannot constitute a convincing logical argument for sparing the minstrel's life (cf. following tôi, like that of 325 and so many other passages)." (Fernández-Galiano, 1992, p. 281). Para P. Pucci esta seria uma das duas leituras possíveis da tradução (ou compreensão) preferida por Monro: "[...] it [i.e. this statement] might put the accent on eoika: 'I am worthy to sing before you as before a god', implying his own exceeding worth: if a god finds my song worthy, you too should find it so." (Pucci, 1987, p. 233). Para o conjunto da interpretação de P. Pucci ver todo o item 6 nesta mesma página 233 do já citado Odysseus polutropos.

${ }^{27}$ Ver o trecho sublinhado (por mim) de M. Fernández-Galiano na nota 24, e o também sublinhado (por mim) de P. Pucci nesta nota seguinte. 
bajulação [...]: 'talvez', como nota Hayman, 'o mais antigo traço de adulação entre bardo e patrão’ na nossa literatura.” (Stanford, 1958, p. 385). ${ }^{28}$

Pietro Pucci, no entanto, estende o alcance da destinação deste canto de Fêmio para este rei (Odisseu), que é como um deus, e engenhosamente passa a pensar o próprio objeto ou tema central deste canto como sendo também, no interesse óbvio de glorificação deste rei divinizado, a história afinal vitoriosa de Odisseu, ${ }^{29}$ numa retratação de sua primeira e falsa história do retorno em que Odisseu é apresentado como já morto (cf. Od. 1, 344-5), retratação que seria a origem da (e coincidiria com a) própria Odisseia. ${ }^{30}$ Ora, seria até mesmo possível pensar que o retorno de Odisseu a Ítaca disfarçado de mendigo, averiguando e sofrendo as injustiças dos pretendentes, para depois castigá-los súbita e terrivelmente (mesmo se aparentemente em situação desfavorável), seguiria um padrão de histórias de theoksenía em que esta função é habitualmente desempenhada por um deus, como bem o demonstrou Emily Kearns no artigo "The Return of Odysseus: A Homeric Theoxeny" (Kearns, 1982). ${ }^{31}$ Mas, ainda assim, se formos sóbrios, constataremos que Fêmio não indica explicitamente nada sobre o conteúdo deste seu futuro canto para Odisseu, este rei divinizado que é o seu novo senhor, assim como deveremos lembrar que o último canto de Fêmio na Odisseia, a pedido do próprio Odisseu, é mais provavelmente um himeneu (ou canto de casamento) na festa fingida de casamento de Penélope com um dos pretendentes (pois todos já estão mortos) no canto 23 (142-52), e que por isso não deveria em princípio ter como protagonista o próprio casal reencontrado.

Vejamos, enfim, dada a vertiginosa quantidade de discussões que suscitou, a primeira - e aparentemente contraditória ou paradoxal - conjunção das esferas divina e humana (após a definição dos destinatários do canto do aedo: "tanto pra deuses quanto pra homens”), descrevendo a atividade ou condição de Fêmio como cantor, na primeira parte

\footnotetext{
${ }^{28}$ Apesar da insistência derridiana na "indecidibilidade" entre as duas interpretações possíveis de éoika, a interpretação final de P. Pucci é, de algum modo, semelhante à de W. Stanford: "In the latter interpretation the worth of the poet is measured by the similar attention that Odysseus and the god offer to Phemius' song. Here again, however, the portrait of the king assumes analogies with that of a god: Phemius sees himself singing before two images, a human one and a divine one, as being concretely in that astonished presence that is described repeatedly in the Odyssey, often with a para- verb." (Pucci, 1987, p. 233, sublinhados meus).

29 “'This statement [i.e. 'I am fit to sing before you as if before a god.'] may imply Phemius' promise to look at the basileus as if he were a god, to sing about him almost as if he were a god." (Pucci, 1987, p. 233, sublinhados meus).

30 'What if the tradition of our Odyssey originates in Phemius' recantation? Otherwise why would the Odyssey bother to dramatize the scene in which Phemius promises to sing before Odysseus as before a god? This promise seems at any rate to be the fictional event from which the song of the Odyssey emerges as the version that triumphs over and silences all the others." (Pucci, 1987, p. 230). ${ }^{31}$ Ver também o modo como S. Douglas Olson utiliza este artigo, trazendo uma série de outras considerações sobre os deuses na Odisseia, no último capítulo ("10. The Return of the God") de Blood \& Iron: Stories \& Storytelling in Homer's Odyssey (Olson, 1995, p. 205-23).
} 
desta súplica: "Sou autodidata, pois um deus no meu senso enredos/ variados faz brotar; [...]." (Od. 22, 347-8).

Tanto a oração principal ("Sou autodidata"), por conter um termo, o predicativo do sujeito, que é um hápax (ocorrência única) em Homero: antodídaktos, traduzido algo convencionalmente aqui ("autodidata", onde o melhor talvez fosse "espontâneo"), quanto a oração subordinada causal ou explicativa ("pois um deus no meu senso enredos/ variados faz brotar"), por depender de uma interpretação pouco usual da partícula dé ("pois", habitualmente traduzida por "e" ou "mas"), colocam delicados problemas de entendimento que condicionam ou repercutem na discussão sobre a relação semântica entre as duas orações e o sentido do conjunto da proposição.

Após estas primeiras indicações e antes de me deter com calma em cada uma destas duas orações, eu retomarei, porém, a discussão mais genérica sobre a relação semântica entre elas, como uma primeira e resumida via de acesso à fortuna crítica sobre esta proposição. Talvez seja possível dizer que a interpretação básica mais comum foi, admitindo uma distinção nítida entre a esfera humana (primeira oração) e a divina (segunda oração), reconhecer em Fêmio como cantor uma certa autonomia (como se demonstrada pela óbvia presença do mesmo prefixo auto- em autodídaktos), seja no aprendizado técnico ou formal do canto (em oposição ao repertório fornecido pelo deus ou a Musa, cf. Lanata), ${ }^{32}$ seja na própria composição do canto (em oposição às composições de outros aedos, cf. Stanford, Murray, Bowie, Segal e De Jong, ou a partir do repertório inicial fornecido pela Musa, cf. Pucci), ${ }^{33}$ seja na escolha ou aplicação (responsabilidade apenas do aedo) do repertório fornecido pelo deus (ou pela Musa) a uma determinada audiência e situação (cf. Fernández-Galiano e Dougherty), ${ }^{34}$ ou, enfim, como se prescindindo da própria Musa, a única que poderia dar

32 "It has been suggested that autodidaktos refers to the technical aspects of composition (form, style etc.), whereas oimas refers to the subject matter of his song [referência a G. Lanata, Poetica pre-Platonica, 1963, p. 13-4], but this seems to me to be too precise a distinction.” (Murray, 1982, p. 97). Uma opção quase invertida seria a de Massimo Pizzocaro, para quem a Musa ensinaria a técnica de composição formular e o aedo "autodidata" (em oposição aos aedos que compõem um épos mítico) comporia um épos histórico (cf. Pizzocaro, 1999, p. 21-2).

33 “autodídaktos is noteworthy: a contrast is perhaps implied with the 'school poets' [...] who in Homer's time very likely derived much of their skill and material from education in poetic technique [...]." (Stanford, 1958, p. 385). "The general point of Phemius' claim is that he does not simply repeat songs he has learnt from other bards, but composes his songs himself.” (Murray, 1982, p. 97, que é retomada na íntegra por E. L. Bowie em "1. Lies, Fiction and Slander in Early Greek Poetry", Bowie, 1993, p. 17). "When he calls himself autodidaktos, he may mean that $[. .$.$] he is not just repeating what$ he has acquired from a specific human teacher or model but is capable of adding or improving on traditional elements." (Segal, 1994, p. 138). Contra, mas supondo uma mesma referência, ver Irene de Jong: "This 'autodidacticism' [...] camouflages a singer's actual training by other singers [...]." (De Jong, 2001, p. 539). "The god would make an initial intervention - a programming as it were - but after that, the poet takes over and teaches himself to cultivate the song." (Pucci, 1987, p. 230).

34 "What he seems to be trying to say, in his desperate plea [...], is that he has an innate capacity to apply the traditional repertory of inherited poetic craft to the particular case relevant to the audience 
ordem (kósmos) aos "enredos" (oímai) implantados por um deus outro que não seria ela (cf. Brandão). ${ }^{35}$

E se, mesmo com algum destes contornos, a distinção primeira entre as duas esferas (a humana e a divina) e uma aparente contradição entre as duas responsabilidades pelo canto pareciam permanecer, o recurso mais comum, como, por exemplo, proposto por Penelope Murray em "Poetic Inspiration in Early Greece" (Murray, 1982, p. 96-7), foi à complementaridade (e não simples oposição) entre as duas distintas esferas, ${ }^{36}$ a partir do conceito da "dupla motivação" proposto no artigo ou monografia célebre de Albin Lesky. ${ }^{37}$

Esta pretensa autonomia (em qualquer uma das quatro modalidades elencadas) é, no entanto, totalmente estranha ao modo de pensar (ou ponto de vista) homérico, ${ }^{38}$ sendo, no caso do aedo ou cantor (como Demódoco), comum - como signo de sua competência narrativa e veracidade - a atribuição à Musa (ou a outra divindade afim, como Apolo) da doação do canto (ou arte de cantar) ou de um impulso, assistência ou ensinamento para o

of the moment." (Fernández-Galiano, 1992, p. 281). "While every oral poet must be fluent in the tradition, the true test of an oral poet's skill is his ability to sing the right song at the right time. [...] the poet must be able to manipulate the vast tradition to fit any given poetic occasion, and for this skill the poet depends only upon himself. Most important, he must tailor his song to each particular audience." (Dougherty, 1991, p. 98).

35 “[...] ao afirmar que aprendeu por si mesmo, não estará se referindo, em vez de a outros aedos, à própria Musa? Com efeito, prescindir do aprendizado da Musa não implicaria que um deus não pudesse fazer brotar em seu ânimo muitos entrechos (oimal) a partir dos quais compunha seus cantos, mas simplesmente que, nesses cantos, falta a operação que é própria da Musa, a qual os tornaria katà kósmon - [...] admitindo que nem toda oíme é katà kósmon, mas apenas aquela ensinada pela Musa." (Brandão, 2005, p. 69).

${ }^{36}$ Uma formulação análoga é proposta por H. Maehler, que insiste também no orgulho de suas próprias habilidades expresso pelo cantor Fêmio: "Thus Phemius is equally proud of having been 'self-taught' (autodídaktos) and of having had various 'ways' of song (oimas) implanted in his mind by a god. For him there is no contradiction between the divine gift and his own hability, since the latter presupposes the former [...]. On the other hand, he is evidently proud of his own creative power." (Maehler, 1999, p. 7).

37 "Göttliche und menschliche Motivation im homerischen Epos." (Lesky, 1961). A. Lesky é a única referência citada por Irene de Jong quando propõe: "Phemius explains his talents as a singer in terms of double motivation: he is both self-taught and taught by a god (for teaching by a god, cf. Demodocus in 8.481 and 488)." (De Jong, 2001, p. 539). Já a formulação de Penelope Murray (seguida, por exemplo, por E. L. Bowie e J. L. Brandão) é a seguinte: "Dual motivation is, of course, a characteristic of Homeric epic and a god's prompting does not exclude a personal motivation. The two halves of Phemius' statement are therefore complementary rather than contradictory: he is both self-taught and the recipient of divine aid.” (Murray, 1982, p. 97).

${ }^{38}$ Também no caso do guerreiro, por exemplo, como várias cenas da Ilíada mostram bem, seria estranha ou mesmo perigosa a pretensão de atuar autonomamente e sem a assistência de uma divindade guerreira como Atena, Apolo ou Posseidon. 
canto (cf. $O d .8,44,64,73,481$ e 488), ${ }^{39}$ tal como se evidencia em todas estas passagens referentes a Demódoco no canto 8 da Odisseia, cujo texto grego primeiramente citamos de modo pontual logo abaixo, para em seguida traduzi-las em sequência e por ordem de aparição, formando um pequeno conjunto demonstrativo.

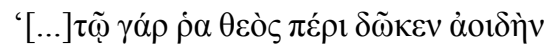

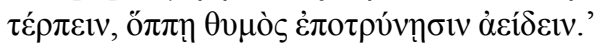

(Od. 8, 44-5)

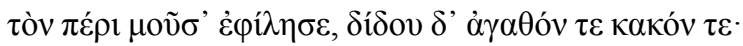

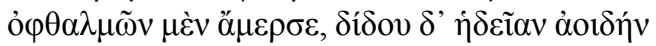

(Od. 8, 63-4)

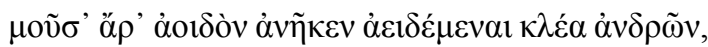

(Od. 8, 73)

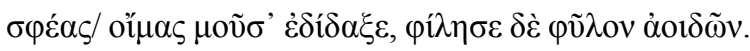

(Od. 8, 480-1)

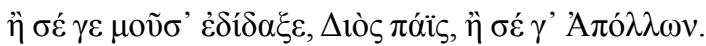

$(\mathrm{Od} .8,488)$

Assim, Alcínoo define Demódoco como "um cantor divino" (theîon aoidón), "pois a ele um deus deu sobremodo o canto/ pra deleitar, por onde o ânimo o incita a cantar" (Od. 8, 44-5, negritos meus nesta e nas outras citações deste parágrafo), em uma conjunção (aparentemente contraditória) da esfera divina e da humana, que é exatamente análoga à proposta por Fêmio em sua súplica. Pouco depois é o narrador quem o diz, ao explicar que "a Musa o ama sobremaneira, pois lhe deu tanto o bem quanto o mal:/ tirou-lhe os olhos, mas deu-lhe o agradável canto" $(\mathrm{Od} .8,63-4)$. Ao descrever o começo da primeira canção de Demódoco (logo após o fim da refeição), o narrador diz: "A Musa impeliu o cantor a cantar os feitos dos varões" (Od. 8, 73). E Odisseu, ao fazer o elogio de Demódoco (ou dos cantores) para o arauto, justificando o dom de um pedaço de lombo de porco para aquele, diz que "a Musa lhes ensina os enredos, pois ama a estirpe dos cantores." (Od. 8, 480-1). E, enfim, ao fazer Odisseu o elogio de Demódoco para o próprio cantor, definindo depois o modo ordenado e acurado (ou veraz) como ele canta o que ocorreu aos Aqueus em Troia, ele diz: "Ou a Musa, filha de Zeus, te (ensinou), ou te ensinou Apolo." (Od. 8, 488).

Seria, portanto, anacrônico e estranho a este padrão positivo de atribuição do canto à Musa (ou a um deus afim) que o cantor Fêmio, suplicando por sua vida, e se propondo

\footnotetext{
${ }^{39}$ Uma oposição ou desafio deliberado às Musas seria algo ainda mais desastroso, como o prova bem o exemplo do cantor Tâmiris que se vangloria de vencê-las, caso disputem, e que por isso não só é por elas privado da visão, como Demódoco, mas perde também o canto (ou arte do canto) divino e a arte de tocar a cítara (cf. Ilíada 2, 594-600, e o comentário de Jacyntho L. Brandão em "Tâmiris", Brandão, 2005, p. 52-5).
} 
como futuro cantor para seu novo senhor, reivindicasse qualquer autonomia como uma espécie de valor "literário" independente e já autoconsciente e crítico.

Por outro lado, com exceção precisamente do ensinamento da Musa (ou de Apolo), definido pelo aoristo edídakese ("ensina" ou “ensinou”), não há em Homero nenhuma indicação de um aprendizado qualquer do cantor com um outro cantor-mestre ou pela frequentação de outros cantores (ou de algo como um grupo ou "escola" de cantores, como teriam sido os Homéridas) - ou tal como é projetado forçadamente o aprendizado ou formação dos guslar na pesquisa de campo da tradição oral serbo-croata por Milman Parry e Albert Lord -, ou ainda pela participação em concursos (como, por exemplo, já em Hesíodo, Trabalhos e dias, 654-7, e depois nos grandes festivais de rapsodos, tal como retratado no Íon de Platão), sendo tanto Fêmio quanto Demódoco, enquanto aedos "oficiais" de um palácio ou uma corte real (a de Ítaca e a dos Feácios), representados em um total isolamento em relação a outros aedos. ${ }^{40}$

Uma vez colocadas estas novas coordenadas interpretativas (a partir da crítica aos já impregnados lugares-comuns da tradição interpretativa), podemos voltar agora com mais calma às duas orações (e o modo de conexão entre elas) que compõem esta proposição de Fêmio. A aparentemente simples oração principal predicativa ("Sou autodidata") coloca como foi indicado há pouco - o problema do sentido preciso do predicativo (do sujeito) autodidaktos, ${ }^{41}$ um hápax homérico, traduzido ou quase transliterado aqui por "autodidata". Que eu saiba, o único comentador a duvidar abertamente deste sentido, e a propor um método mais razoável (e comparativo) para tentar estabelecê-lo, foi William G. Thalmann em Conventions of Form and Thought in Early Greek Epic Poetry (Thalmann, 1984). Ao comentar esta proposição de Fêmio, ele diz: "A palavra autodídaktos [...] não deveria ser entendida aqui como signo de uma aquisição de conhecimento puramente pessoal que é independente de uma ajuda externa, como a expressão 'autodidata' ['self-taught'] implicaria [...]. Neste contexto,

\footnotetext{
${ }^{40}$ Graham Wheeler (em "Sing, Muse...: The Introit from Homer to Apollonius") parece ser um dos únicos a admiti-lo explicitamente, o que coincidentemente traz alguma decisiva consequência sobre o modo também pouco comum como ele interpreta o autodídaktos do discurso de Fêmio: "Finally, it would have been obvious that bards had to learn, probably by means of long apprenticeships, the technical skills and poetic subject-matter essential to their craft, a fact which Homer suppresses: the description of Phemius as autodidaktos at $O d$. 22.347-8, which seems at first sight to tell against this point, probably refers to inborn talent (it is significant, for example, that edidakse is applied twice to the Muses' action on Demodocus at 8.479-81 and 487-8)". (Wheeler, 2002, p. 37, os sublinhados são meus).

41 “autodídaktos [...], self-tanght, Od.22.347; au. ésōthen thumós A. Ag. 991 (lyr.); philosophía D.H.5.12; of instinct, tò tôn orgánōn au. Gal.8.445.” (Liddell-Scott, 1977, p. 280). “autodídaktos [autós + didak, didáskō]. Self-taught kh 347.” (Cunliffe, 1988, p. 62). “auto-dídaktos qui ipse se docuit, magistro non usus. kh 347 autodídaktos d'eimí.” (Ebeling, 1987, p. 200).
} 
autodídaktos significa mais provavelmente uma habilidade inata exercida espontaneamente, sem a vontade consciente." (Thalmann, 1984, p. 126, tradução minha). ${ }^{42}$

E o modo como ele chega a isso é pela comparação com uma também ocorrência única do termo em Ésquilo, que o usa também em conexão com o canto. $\mathrm{O}$ coro do Agamêmnon (no terceiro estásimo) descreve assim a maneira como alguns deles sentem medo involuntariamente, sem um conhecimento consciente de sua causa:

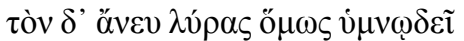

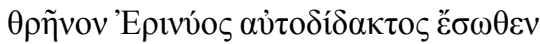

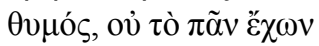

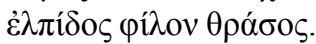

"Sem lira hineia a nênia de Erínis

íntimo ímpeto instruído por si mesmo [autodidaktos]

sem que tenha toda

sua audácia de esperança."

(Agamêmnon 990-4, tradução de Jaa Torrano,

negritos meus, assim como a inclusão do termo grego). ${ }^{43}$

Eis o comentário de William G. Thalmann: "Aqui autodídaktos significa quase o mesmo que 'espontaneamente'. ${ }^{44}$ No verso odisseico também, ele provavelmente implica a retirada do canto do interior do cantor, sem seu controle deliberado. As duas orações da frase de Fêmio descrevem, então, a mesma coisa [...] a partir de visões da sua causa que são diferentes, mas não irreconciliáveis. Pois faz pouca diferença se o canto é referido a uma fonte interna ou a uma causa externa e divina". (Thalmann, 1984, p. 127, tradução minha).

${ }^{42}$ Um outro estudioso, no entanto, a propor algo de semelhante, foi Carlo Brillante (no artigo "Il cantore e la Musa nell'epica greca arcaica"), para quem autodídaktos denotaria "colui che ha appreso da sé, il cui sapere è quindi ‘spontaneo'; ciò distingue il sapere del cantore da quello degli altri uomini, que per l'apprendimento dipendono da altri [...]”, e que, portanto, diz que: “[...] dichiarondosi autodídaktos, Femio ribadisce che i canti da lui eseguiti non sono stati appresi da altri o influenzati da circostanze esterne, ma gli sono stati communicati diretamente dalla divinità. [...] Femio cioè sorvola proprio sugli aspetti tecnici e sulle circostanze esterna della performance, che potevano far dubitare Odisseo di una sua solidarietà con i pretendenti, e si appela all'origine divina della sua poesia”. (Brillante, 1992, p. 13-5). ${ }^{43} \mathrm{O}$ texto grego utilizado é o estabelecido por J. D. Denniston e D. L. Page (Aeschylus, Agamemnon. Denniston-Page, 1986). A tradução, como já indicada, é a de Jaa Torrano (Ésquilo, Orestéia I: Agamêmnon. Torrano, 2004, p. 171). Foi cotejada também a de Paul Mazon, assim como o texto grego por ele estabelecido (Eschyle, Agamemnon, Les Choéphores, Les Euménides. Mazon, 1983).

${ }^{44}$ Em uma nota a esta proposição, W. G. Thalmann cita dois comentários do Agamêmnon de Ésquilo que ainda hoje são referência, o de Denniston-Page e o de Eduard Fraenkel: “Spontaneous' is the explanation of Denniston and Page (1957), 156. Cf. Fraenkel (1950) II, 451: 'The thumós, which learned it [the song of fear] from no one, sings it from within' (emphasis added).” (Thalmann, 1984, p. 224). Eis diretamente (e na íntegra) o comentário de Denniston-Page sobre o termo em questão no verso 994: "992. autodídaktos: i.e. spontaneous; so in 979 the song is akéleusthos ámisthos, it comes unbidden, unhired, self-taught.” (Denniston-Page, 1986, p. 156). 
Talvez coubesse aqui precisar que a dificuldade de compreender estas duas dimensões (a humana e a divina) de um mesmo fenômeno extraordinário (o canto em ato e eficaz) venha de uma lógica dualista (e da exclusão) que supõe que se uma divindade externa e antropomórfica, ou seja: transcendente, é o agente determinante de uma ação humana, ela não poderia ser sentida interna ou imanentemente pelo humano que a experimenta, quando justamente (e ao contrário disso) os dois fenômenos coincidem e o agente humano se sente, no instante mesmo de sua maior potência e efetividade, como se fora de si mesmo e habitado por um outro maior (o deus desta atividade) que transborda a sua pequena consciência pessoal. ${ }^{45}$

Vejamos, enfim, a segunda oração que compõe esta segunda proposição justificativa (da primeira metade da súplica) de Fêmio: "pois um deus no meu senso enredos/ variados faz brotar" (Od. 22, 347-8). Antes de comentar a interpretação já indicada da partícula dé como causal ou explicativa e sua tradução por "pois" (decidindo o modo de conexão entre as duas orações), detenhamo-nos com mais atenção nos outros elementos da oração.

O seu sujeito, theós ("um deus" ou "uma divindade”), guarda alguma indeterminação e tende a ser geralmente compreendido - dada a atividade do cantor - como designando a Musa, algo que ocorre também na descrição de Demódoco por Alcínoo $(O d .8,44-5)$, ainda que, como acontece no elogio direto a Demódoco feito por Odisseu $(\mathrm{Od} .8,488)$, ele pudesse ser também Apolo, outro deus tradicionalmente associado ao canto e à lira (cf. Hesíodo, Teogonia, 94-5). ${ }^{46}$ De qualquer modo, o mais importante é a presença ou ação deste deus, tornando assim o canto e o próprio cantor de algum modo divinos ou divinizados.

O seu objeto, oîmas pantoîas ("enredos variados”), tem como núcleo um substantivo (aqui no acusativo plural), oímē, cujo sentido preciso também é objeto de discussão, pois sua associação com oîmos ("caminho") - donde metaforicamente "o caminho do canto" ("way of song", "marche d'un récit"), ${ }^{47}$ interpretável como "enredo" ou "entrecho" - é considerada, apesar de plausível, apenas uma espécie de etimologia popular por Pierre Chantraine, que opta pelo sentido simples de "canto, poema, relato poético". ${ }^{48}$ Minha opção de leitura

\footnotetext{
${ }^{45}$ Em uma tentativa de definição do que estaria sendo divinizado na Musa, Marcel Detienne, no capítulo 2 do muito lido Les maîtres de verité dans la Grèce archaïque, ao propor que um nome comum moûsa (cujo sentido seria o de "palavra cantada", "palavra ritmada") corresponde no plano profano à Musa personalizada do panteão grego, faz a seguinte proposição citando J.-P. Vernant: "Mô̂sa est une de ces puissances religieuses qui débordent l'homme 'alors même qu'il en éprouve au dedans de lui la présence"”. (Detienne, 1981, p. 9-10).

${ }^{46}$ Estas opções já estavam presentes nas anotações de um escoliasta (o H) da Odisseia: "347. theós] he moûsa. ei ge mè haútai mèn áidousin, phormízei dè ho Apóllōn. ("347. um deus] a musa. Se estas (por um lado) não cantam, Apolo (por outro) toca a lira.”). (Dindorf, 1855, p. 713).

47 "oímē, he = oîmos: metaph., way of song, song, lay [...]." (Liddell-Scott, 1977, p. 1206).

“oímēe ès (he) marche d'un récit, d'où récit, poème (...). (cf. oîmos)." (Bailly, 1967, p. 1358). “oímē (...), cursus, via, deinde: Gang, den eine Erzählung nimmt, narratio, canticum (...).” (Ebeling, 1987, p. 35). 48 “oímē: f. «chant, poème, récit poétique » (Od., A.R., Call., etc.). [...] Et. : En raison de certains tours où oîmos est employé à propos des poèmes, oîmos aoidês (H. Herm. 451), epéón oîmos (Pi. O. 9,47) [...], on a tiré oímē de oîmos « marche, chémin » (le terme appartiendrait au vocabulaire des aèdes), cf. surtout
} 
e tradução, apenas possível (cf. tradução de Christian Werner), aposta na prioridade do elemento narrativo em Homero (em detrimento do formal ou métrico-formular, que jamais é explicitado) e, neste, do que poderíamos chamar aproximativamente de "argumento" ou "roteiro" da história, como se o deus fizesse brotar, "no senso" (ou "juízo", cf. tradução de Christian Werner para en phresín) do cantor, sobretudo um repertório de "enredos" de histórias, que para a diversidade possível de ocasiões de canto e de audiências - mesmo no palácio do seu senhor Odisseu e devendo primeiramente agradar a ele - devem ser "variadas" ou "de todo o tipo" (pantoîas).

O seu verbo, enéphusen "faz brotar em" (ou "implanta"), que no aoristo também é um hápax homérico, ${ }^{49}$ curiosamente é uma imagem vegetal ou botânica, diferente da do plano diretamente humano (ou de relação do humano com o divino) presente em um verbo como edídakse ("ensinou" ou "ensina"), imagem (ou metáfora) que sugere um processo vivo e orgânico de algo que nasce de repente e como se milagrosamente, que condiz muito bem com o sentido de "espontâneo" (ou "sem o controle da vontade consciente"), reconstruído comparativamente por W. G. Thalmann, para o termo autodidaktos, criando um conjunto que parece se caracterizar pela fluidez e a ausência de esforço.

Esclarecido, assim, a partir destes elementos básicos, o conjunto desta oração ("um deus no meu senso enredos/ variados faz brotar"), assim como o sentido de autodídaktos (antes "espontâneo" do que "autodidata" no sentido literal) na oração "principal" ("Sou autodidata"), a conexão paratática entre as duas orações (em princípio, apenas coordenadas) por meio da partícula dé passa a poder ser lida como sendo de natureza causal ou explicativa ("pois", e não "e" ou "mas"), o que é uma possibilidade bastante comum em Homero, tal como bem indicado tanto por Pierre Chantrain $e^{50}$ quanto por J. D. Denniston, que esclarece (mesmo que seus exemplos não incluam esta ocorrência homérica) assim: "dé por gár. Isso é bastante comum, não somente em Homero, onde deveríamos esperar achá-lo, mas também em um estilo mais tardio e logicamente mais desenvolvido. Os escólios observam com frequência: ho dé antì toû gár ["o dé no lugar do gár"] (Ver Tucker sobre Ésq. Coéf. 32)." (Denniston, 1954, p. 169, tradução minha).

Becker, Das Bild des Weges 36 sq., 68 sq. [...]. Cette vue est plausible. On ne peut évidemment réfuter l'objection qu'il s'agirait d'un rapprochement par étymologie populaire." (Chantraine, 1968, p. 783). 49 "[...] he [i.e. Phemius] uses the hapax emphrio [...] to describe his inspiration: 'the god has implanted all kinds of song (lit. 'all ways, paths' [...]). The more usual word for divine mental 'implantation' is the aor. of tithèmi, used six times in the Odyssey for Athena's suggestions (e.g. Od. V 427 epi phresi thêkee; cf. xxi 1), or for suggestions by the theós in general (xiv 227), by Zeus (xvi 291), by the Erinys (xv 234), by Teiresias in Hades (xi 146); only once do we find the expression enépneuse phresi daimōn, of a god suggesting the ruse of Penelope's weaving in xix 138 [...].” (Fernández-Galiano, 1992, p. 280-1). 50 “517. Dans une succession de propositions indépendantes, il arrive souvent chez Homère, comme dans le grec postérieur, que, de deux propositions coordonnées par dé, l'une soit logiquement équivalente à une subordonnée qui dépendrait de l'autre. Propositions de valeur causale : D 438 allà glôss' emémikto, polúklètoi d'ésan ándres 'les langues se sont mélangées, (car) ce sont des gens venus de tant de pays' ; [...]." (Chantraine, 1981, p. 357). 
Mas, mesmo entre os comentadores mais reconhecidos de Homero, esta ocorrência do dé pôde ser lida, ainda que apenas excepcionalmente, como eu a estou lendo agora. É o caso de Ameis-Hentze que anotam (em seus comentários para uso nas escolas alemãs do século XIX): “347. autodídaktos 'auto-educado'. - theós dé 'pois a divindade'; por isso ele não precisou de instrução em uma escola de cantores. A Musa como professora também em th 64. 480f." (Ameis-Henze, 1911, p. 121, tradução minha). Como já indicamos, na representação homérica dos cantores (ou aedos) não há lugar para um aprendizado com outros mestres-cantores, nem nenhum tipo de escola, sendo a Musa a única professora. E se, como quer P. Pucci, o narrador (ou poeta) da Odisseia coloca limites ao poder da Musa ou insinua questões quanto a ele, ${ }^{51}$ isso não faz com que a representação interna dos cantores deixe de privilegiar sua relação com a Musa (como signo do poder e eficácia deles) e de desprezar qualquer relação destes com outros cantores ou mestres humanos possíveis, assim como qualquer traço de autonomia.

Assim sendo, com o deslocamento da importância desta proposição de Fêmio para o papel proeminente da divindade (a Musa ou Apolo), que de algum modo também o diviniza, valorizando-o ao máximo, Fêmio certamente quer justificar antecipadamente sua "competência" como o futuro cantor (no palácio de Ítaca) de seu reassumido rei e senhor (também de algum modo divinizado) Odisseu.

\section{REFERÊNCIAS}

\section{FONTES PRIMÁRIAS}

AESCHYLUS. Agamemnon. Edited with Introduction and Commentary by J. D. Denniston and D. L. Page. Oxford: Oxford University Press, 1986. First Edition, 1957.

DINDORF, W. (ed.). Scholia Graeca in Homeri Odysseam. Oxonii: E Typographeo Academico, 1855.t. 2.

ESCHYLE. Agamemnon, Les Choéphores, Les Euménides. Texte établi et traduit par Paul Mazon. Paris: Les Belles Lettres, 1983. $1^{\text {ère }}$ édition, 1925.

ÉSQUILO. Orestéia I: Agamêmnon. Estudo e tradução de Jaa Torrano. São Paulo: Iluminuras/ Fapesp, 2004.

HOMERI OPER A tomus IV - Odysseae XIII-XXIV. Edited by Thomas W. Allen. $2^{\text {nd }}$ ed. Oxford: Oxford University Press, 1919.

HOMERI Odyssea. Recognouit Helmut van Thiel. Hildesheim: Olms, 1991.

\footnotetext{
51 “'According to this reading [i.e. of Ameis-Henze-Cauer], 'self-taught' would mean 'with no [school] knowledge' and therefore 'exclusively inspired' by the Muses. This interpretation would reduce the collaboration that Phemius describes to a one-dimensional act." (Pucci, 1987, p. 230, n. 9. Para esta questão ver não só o conjunto desta nota, mas também o conjunto dos itens 3 , 4 e 5 deste capítulo já citado do livro de P. Pucci).
} 
HOMERI Odyssea. Recognouit Peter von der Mühll. Basel: Helbing \& Lichtenhahn, 1962. Erste Auflage, 1940.

HOMERO. Odisseia. Tradução de Frederico Lourenço. Lisboa: Cotovia, 2003.

HOMERO. Odisseia. Tradução de Christian Werner. São Paulo: Cosac Naify, 2014.

\section{FONTES SECUNDÁRIAS}

AMEIS, K. F.; HENZE, C. Homers Odyssee - für den Schulgebrauch erklärt - Zweiter Band, Zweites Heft, Gesang XIX-XXIV . Leipzig: Teubner, 1911.

BAILLY, M. A. Dictionnaire Grec-Français. Paris: Hachette, 1967.

BOWIE, E. L. 1. Lies, Fiction and Slander in Early Greek Poetry. In: GILL C.; WISERMAN T. P. (org.). Lies and Fiction in the Ancient World. Austin: University of Texas Press, 1993, p. 1-37. BRANDÃO, J. L. 3. Cantores. In: . Antiga Musa (arqueologia da fição). Belo Horizonte: Faculdade de Letras da UFMG, 2005, p. 51-73.

BRILLANTE, C. Il cantore e la Musa nell'epica greca arcaica. Rudiae, v. 4, p. 5-37, 1992.

CHANTRAINE, P. La structure de la phrase complexe et la parataxe. In: .Grammaire bomérique II: Syntaxe. Paris: Klincksieck, 1981, p. 351-364. $1^{\text {ère } e ́ d i t i o n, ~} 1953$.

CHANTRAINE, P. Dictionnaire étymologique de la langue grecque 3-4. Paris: Klincksieck, 1984.

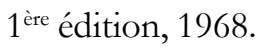

CUNLIFFE, R. J. A Lexicon of the Homeric Dialect. Norman: University of Oklahoma Press, 1988. First Edition, 1924.

DENNISTON, J. D. The Greek Particles. Oxford: Oxford University Press, 1954. First Edition, 1934.

DETIENNE, M. II. La mémoire du poète. In: archaïque. Paris: François Maspero, 1981, p. 9-27. $1^{\text {ère édition, } 1967 .}$ . Les maîtres de verité dans la Grèce

DOUGHERTY, C. Phemius' Last Stand: The Impact of Occasion on Tradition in the Odyssey. Oral Tradition, v. 6, n. 1, p. 93-103, 1991.

EBELING, H. Lexicon Homericum. Hildesheim: Georg Olms Verlag, 1987. 1. Auflage, 1885. FERNÁNDEZ-GALIANO, M. A Commentary on Homer's Odyssey. Oxford: Oxford University Press, 1992, v. 3, p. 129-310.

de JONG, I. A Narratological Commentary on the Odyssey. Cambridge: Cambridge University Press, 2001.

KEARNS, E. The Return of Odysseus: A Homeric Theoxeny. Classical Quarterly v. 32, p. 2-8, 1982. 
LESKY, A. Göttliche und menschliche Motivation im homerischen Epos. Sitzungsbericbte der Heidelberger Akademie der Wissenschaften, Phil. hist. kl., v. 4, p. 1-52, 1961.

LIDDELL, H. G.; SCOTT, R. A Greek-English Lexicon. Oxford: Clarendon Press, 1977. First Edition, 1843.

MAEHLER, H. The Singer in the Odyssey. In: de JONG, Irene (org.). Homer: Critical Assessments. London: Routledge, 1999. v. 4, p. 6-20.

MURRAY, P. Poetic Inspiration in Early Greece. Journal of Hellenic Studies, v. 101, p. 87-100, 1982.

OLSON, S. D. 10. The Return of the God. In: . Blood \& Iron: Stories \& Storytelling in Homer's Odyssey. Leiden: Brill, 1995, p. 205-223.

PIZZOCARO, M. Il canto nuovo di Femio. Le origini dell'epos storico. Quaderni Urbinati di Cultura Classica, v. 61, p. 7-33, 1999.

PUCCI, P. 21. Phemius and the Beginning of the Odyssey. In: . Odysseus Polutropos: Intertextual Readings in the Odyssey and the Iliad. Ithaca: Cornell University Press, 1987, p. 228-235.

SEGAL, C. 6. Bard and Audience in Homer. In: Ithaca: Cornell University Press, 1994, p. 113-141. . Singers, Heroes and Gods in the Odyssey.

STANFORD, W. S. Commentary on the Odyssey of Homer. $2^{\text {nd }}$ ed. London: St. Martin's Press, 1958. v. 2.

THALMANN, W. G. 4. The poets on their art, I: The performance of hexameter poetry. In: . Conventions of Form and Thought in Early Greek. Epic Poetry. Baltimore: The Johns Hopkins University Press, 1984, p. 113-133.

WHEELER, G. Sing, Muse...: The Introit from Homer to Apollonius. Classical Quarterly, v. 52, n. 1, p. 33-49, 2002. 